\title{
EFFECTIVENESS OF COMPLEX THERAPY FOR ENDOMETRIOID OVARIAN CYSTS DEPENDING ON THE PRESENCE OR ABSENCE OF UNDIFFERENTIATED DYSPLASIA OF CONNECTIVE TISSUE
}

\author{
Aleksanova E. M. , Aksenenko V. A.
}

Stavropol State Medical University, Russian Federation \begin{abstract}
ndometrioid cysts were first described by Rüssel (1899) and Pick (1905), who called them the "chocolate" or "tar" cysts [16]. Considering the frequency of lesions of the genital system, endometrioid ovarian cysts occupy the second place $[1,7,13]$. Despite the studies of over a century years there is still no consensus about the mechanisms of pathogenesis, occurrence and recurrence.
\end{abstract}

Such as therapy for endometrioid formations of the ovaries which are also ambiguous. According to modern concepts, the most positive effects in treatment were shown when using a three-phase approach, including a surgical stage, an antirelapse hormonal therapy and a re-laparoscopy $[6,8]$. The main criterion for the effectiveness of therapy, regardless of method or combinations, show no recurrence of the disease $[8,11,17]$. Relapses of endometrioid ovarian cysts for 5 years after laparoscopic treatment (cystectomy, resection of the ovary, adnexectomy) occur in 10-25\% of cases, and significantly more frequently in patients not treated with hormonal therapy in the postoperative period $[9,15]$. Undifferentiated dysplasia of connective tissues genetically determined developmental disorder of connective tissue, resulting in the change of its structure, functions and properties which cause organ manifestations flowing with human immunity, contributing to the progression of pathological changes in the genital organs. In modern gynecology many studies confirm the impact of undifferentiated dysplasia of connective tissues in the development of gynecological diseases [2, 3, 4, 5, 10, 14].

Despite the interest of researchers about undifferentiated dysplasia of connective tissues, so far there are no research on the effectiveness of standard therapy for endometrioid ovarian cysts, depending on the degree of concomitant undifferentiated dysplasia of connective tissues.

Objective: evaluation of effectiveness of complex therapy of endometrioid ovarian cysts depending

\footnotetext{
Aleksanova Ekaterina, Assistant of obstetrics

and gynecology department, Stavropol State Medical University;

tel.: +79280069003; e-mail: alexanova@mail.ru

Aksenenko Victor, MD, PhD, Professor,

Head of the obstetrics and gynecology department,

Stavropol State Medical University; tel.: +78652716536
}

on the availability of undifferentiated dysplasia of connective tissues.

Material and Methods. Under our supervision there were 70 patients aged from 18 to 40 years, depending on the presence or absence of undifferentiated dysplasia of connective tissue they were divided into 2 groups: I study group consisted of 35 patients with endometrioid ovarian cysts, who wereidentified to have more than 6 external phenotypic traits of undifferentiated dysplasia of connective tissues, II a comparison group consisted of 35 patients with endometrioid ovarian cysts with 6 and less phenotypic traits of undifferentiated dysplasia of connective tissues.

To externally establish the phenotype a modified phenotypic map was used, including 63 metric units [12]. Patients of the main group and comparison group did not differ in age, complaints, reproductive and somatic factors, gynecological pathologies and the state of endometriosis. All the patients had not received specific therapy of endometriosis before the surgery. All patients diagnosed for endometrioid ovarian cysts were confirmed histologically. for all the patients after a complete observation a laparoscopy was performed, followed by theremoval of cysts in healthy tissues, separation of adhesions, hydrotubation. After surgery the patient of both groups within 6 months received an agonist Gonadotropin releasing hormone «Buserelindepot» («pharmsintez», Russia): intramuscularly in a dose of $3.75 \mathrm{mg}$ once every 28 days for 6 months. For the comparative evaluation of the clinical effect of complex therapy for endometrioid ovarian cysts, the patients were observed and monitored the frequency of detection of pain syndrome, menstrual function, the level of CA-125 (through 1, 3, 6 and 12 months after completion of treatment), as well as infertility within 12 months after the treatment. In the absence of pregnancy after 12 months after completion of treatment, a second-look laparoscopy was performed to estimating the frequency of possible recurrence of endometrioid ovarian cysts. laparoscopy evaluated the state of organs of the pelvis area and abdomen, in case of endometriosis taking into account their size, color, location, extent, and depth of invasion, the severity of adhesions and patency of the fallopian tubes. After which a standard volume of operative 
interventions were conducted, depending on the extent of damage to the tissues.

Statistical data processing was performed on a computer running PENTIUM IV with the use of the program «Statistica 6.0» [9]. In accordance with the purposes and objectives of the study, as well as taking into account the specifics of the analyzed variables the elementary statistics were solved with (mean values $(\mathrm{M})$, medium errors $(\mathrm{m})$, calculation of shares (\%), standard error of the proportion $(\mathrm{N})$ ); comparison of the qualitative parameters in the groups studied with the help of non-parametrical methods 2, Fisher's adjusted Yeats; comparison of quantitative indicators using the nonparametric criterion Mann - Whitney. The criterion for statistical validity of the obtained conclusions was $p<0.05$, as considered in conventional medicine.

Results and Discussion. Complaints on pain syndrome before the treatment were $100.0 \%$ from all the patients, regardless of undifferentiated dysplasia of connective tissues. 1 month after treatment there were no complaints of pain syndrome. 3 months after the end of therapy in the primary group and in the comparison group pain syndrome was reported in 3 patients $(8,6 \pm 4.7 \%) .6$ months after completion of therapy in the main group the resumption of the pain syndrome was observed in $10(28.6 \pm 7.6 \%)$ patients, and in the group without undifferentiated dysplasia of connective tissues -6 patients $(17.1 \pm 6.4 \%)$. After 12 months of monitoring, the number of patients with pain syndrome in the main group increased to $12(34.3 \pm 8.0 \%)$, and in the group of comparison up to $8(22.9 \pm 7.1 \%)$ (Fig. 1$)$.

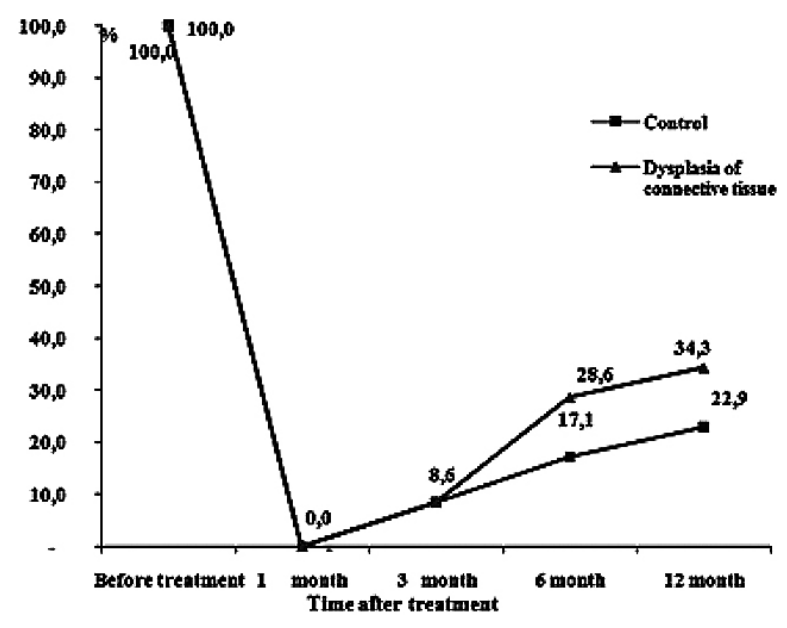

Fig. 1. Dynamics of pain syndrome in patients with endometrioid ovarian cysts depending on the presence or absence of undifferentiated dysplasia of connective tissue one year after completion of therapy.

Before starting therapy, the symptoms of menstrual function disorders were detected in $18(51,48,4 \%)$ patients of the main and $17(48,68,4 \%)$ patients in the comparison group

1 month after the end of therapy complaints of menstrual dysfunction in both groups were noted. 3 months after the treatment of various disorders of the menstrual cycle met in one patient in each group. At the end of 6 months after completion of therapy menstrual irregularities observed in a three cases-by $8.6 \pm 4.7 \%$ patients in each group. After 12 months of monitoring, the number of patients with menstrual cycle in the main group was 4 , and in the group of comparison was 3 patients $(11.4 \pm 5.4 \%$ and $8.6 \pm 4.7 \%$, respectively) (Fig. 2).

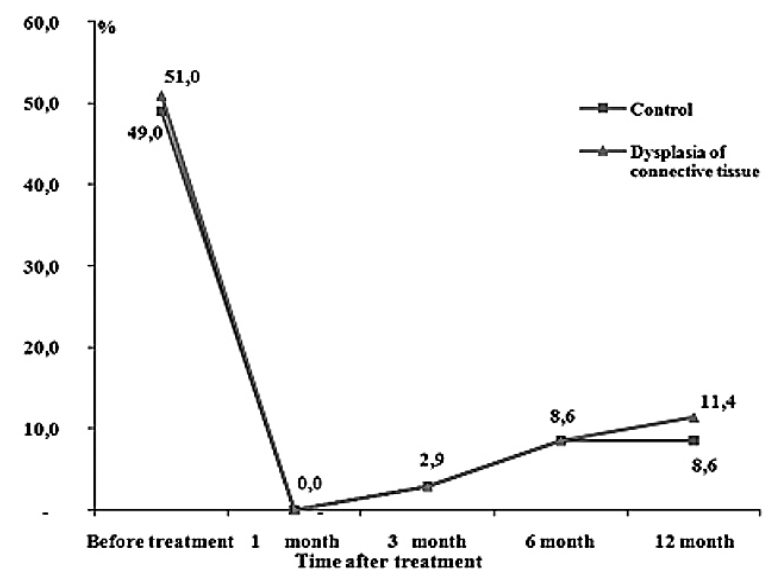

Fig. 2. Dynamics of menstrual disorders in patients with endometrioid ovarian cysts depending on the presence or absence of undifferentiated dysplasia of connective tissue one year after completion of therapy

The content of serum CA-125 blood above $35 \mathrm{IU} /$ $\mathrm{ml}$ was determined in 24 patients of main group and 22 patients in the comparison group $(68.6 \pm 8.3 \%$ and $62.9 \pm 8.2 \%$, respectively).

1 month after completion of treatment the level of CA-125 above $35 \mathrm{IU} / \mathrm{ml}$ was not registered in any group studied. 3 months after completion of treatment the increase in the concentration of CA-125 in peripheral blood were observed in $1(2.9 \pm 2.8 \%)$ patient of the main group and $1(2.9 \pm 2.8 \%)$ patient in the comparison group. 6 months after completion of therapy noted an increase in the concentration of CA-125 in $6(17.1 \pm 6.4 \%)$ patients of main group and $3(8.6 \pm 4.7 \%)$ patients in the comparison group. By the end of the year noted a growth in the number of patients with elevated CA-125 in the peripheral blood. Increase of CA-125 shown in $8(22.9 \pm 7.1 \%)$ patients of main group and in $4(11.4 \pm 5.4 \%)$ patients in the comparison group (Fig. 3 ).

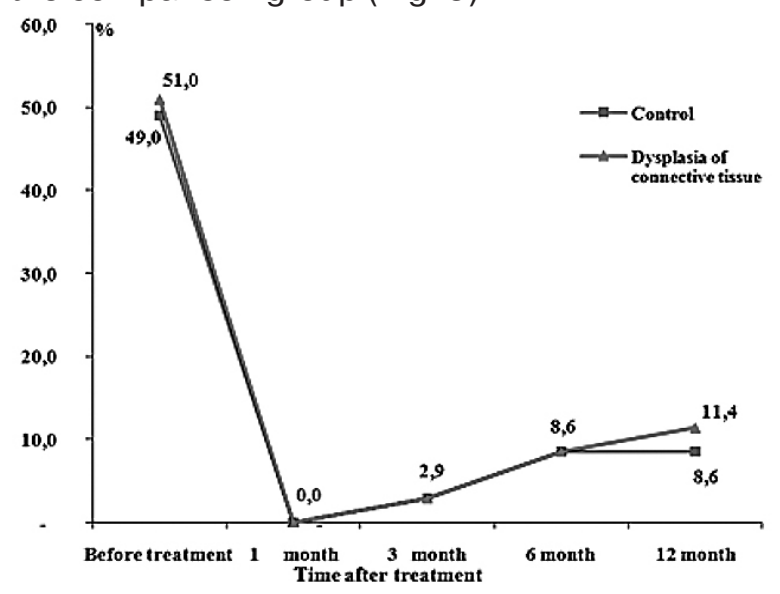

Fig. 3. Dynamics of the level of CA-125 in the peripheral blood of patients with endometrioid ovarian cysts depending on the presence or absence of undifferentiated dysplasia of connective tissue one year after completion of therapy 
Before the beginning of the treatment infertility was observed in $13(37.1 \pm 8.2 \%)$ patients of main group and $12(34.3 \pm 8.0 \%)$ patients in the comparison group.

3 months after completing therapy pregnancy occurred in 2 patients with infertility in the group of comparison and 1 patients of the main group (16.7 $\pm 10.8 \%$ and $7.7 \pm 7.4 \%$, respectively). After 6 months after completion of therapy pregnancy occurred in $5(41.7 \pm 14.2 \%)$ patients in the comparison group and $4(30.8 \pm 12.8 \%)$ patients of the main group. After 12 months pregnancy reporteded in $7(58.3 \pm 14.2 \%)$ patients without undifferentiated dysplasia of connective tissue and $5(38.5 \pm 13.5 \%)$ patients with undifferentiated dysplasia of connective tissue (Fig. 4).

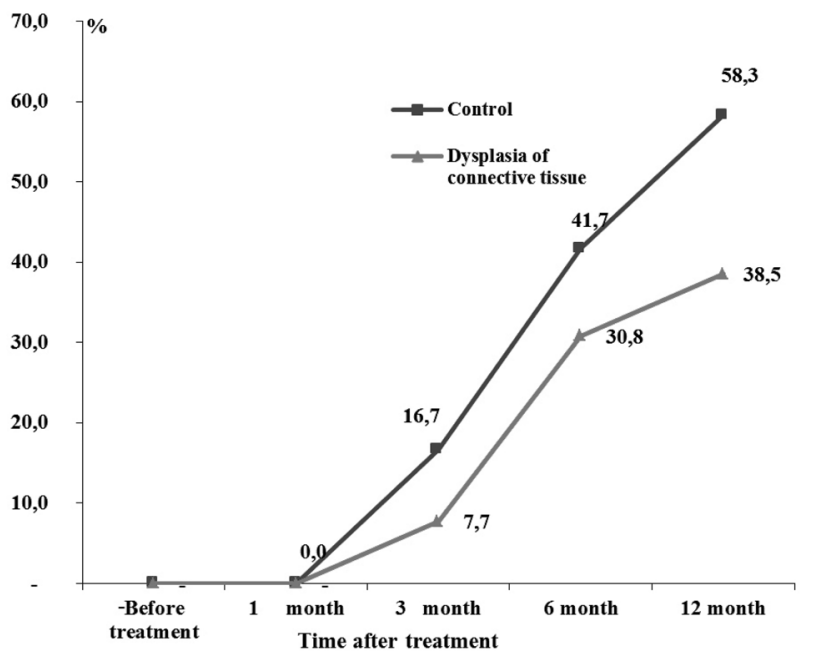

Fig. 4. Pregnancy rate in patients with infertility associated with endometrioid ovarian cysts depending on the presence or absence of undifferentiated dysplasia of connective tissue one year after completion of therapy

In accordance with the developed research Protocol 12 months after completion of treatment of all non-pregnant women with endometrioid ovarian cysts, a second laparoscopy was performed (30 patients of main group and 28 patients of comparison group).

When performed a re-laparoscopy foci of endometriosis in the pelvic peritoneum or ovaries were found in 14 patients with undifferentiated dysplasia of connective tissue $(40.0 \pm 8.3 \%)$ and $7(20.0 \pm 7.1 \%)$ patients without undifferentiated dysplasia of connective tissue.

\section{References}

1. Adamyan L. V., Kulakov V. I., Andreeva E. N. Endometriosis: a Guide for physicians. M; 2006. P. 416.

2. Vereshchagin G. N. Systemic dysplasia of connective tissue. Guidelines for physicians. Novosibirsk; 2008. P. 35.

3. Gromov O. A., Torshin I. Y. Dysplasia of connective tissue, cell biology and molecular mechanisms and the influence of magnesium. Russian journal of medicine. 2008;16(1):110.

4. Zemcovskis E. V. Century Dysplastic phenotypes. Displastice heart. 2007. P. 80.

5. Klemenov A. V., Tkachev O. N., Vertkin A. L. Connective tissue dysplasia and pregnancy (review). Therapeutic archives. 2004;11:80-83.
In case of recurrence of disease, foci of endometriosis were localized on the peritoneum sacroiliac ligaments and in the ovaries, and less frequently localized in the retro-peritoneum space and broad uterine ligaments. Identified relapses of endometrioid ovarian cyst shad not exceed the diameter of $3 \mathrm{~cm}$ and were always unilateral. It should be noted that the localization of foci of endometriosis is not dependant on the presence or absence of undifferentiated dysplasia of connective tissue.

When performed a re-laparoscopy presence of an adhesive process was detected in 15 $(42.9 \pm 8.4 \%)$ patients of main group and in 10 $(28.6 \pm 7.4 \%)$ patients in the comparison group.

Conclusion. Summarizing the data obtained, it can be argued that while conducting the same complex therapy for endometrioid ovarian cysts with the presence of undifferentiated dysplasia of connective tissue, return rate of the pain syndrome after treatment is 1.5 times higher than in the comparison group $(34.3 \pm 8.0$ and $22.9 \pm 7.1 \%$ of patients, respectively). A similar pattern was seen in the study of the content of serum CA- 125 blood: increase of more than $35 \mathrm{IU} / \mathrm{ml}$ a year after completion of treatment is 2 times more frequently observed in patients with undifferentiated dysplasia of connective tissue than in patients in the comparison group (22.9 $\pm 7,1 \%$ and $11.4 \pm 5.4 \%$ of patients, respectively). Atthe same time, studying the frequency of pregnancy in women with endometrioid ovarian cysts, it was found that when the number of phenotypic traits ofundifferentiated dysplasia of connective tissue were less than 6 the pregnancy rate was 1.4 times higher than in the patients with the phenotypic traits of undifferentiated dysplasia of connective tissue more than $6(58.3 \pm 14.2$ and $38.5 \pm 13.5 \%)$.

It should be noted that according to the laparoscopy, recurrence of external genital endometriosis was observed in almost one third of patient with endometrioid ovarian cysts. While in the group of patients with undifferentiated dysplasia of connective tissue endometriosis recurrence rate was 2 times higher than in patients without undifferentiated dysplasia of connective tissue $(40.0 \pm 8,3$ and $22.9 \pm 7.1 \%$, respectively), and the frequency of adhesion processesin the pelvic were 1.5 times $(42.9 \pm 8.4$ and $28.6 \pm 7.4 \%$, respectively).

6. Krasnopolsky V. I., Buyanova S. N. Conservative surgical treatment of the external-internal endometriosis. Journal of obstetric and gynecological diseases. 2002; LI(3):113116.

7. Linde V. A., Whaling, Nahalkova, Nesibaigia O. I. Grishanin Epidemiological aspects of genital endometriosis. Problems of reproduction. 2008;14(3):68-72.

8. Savelyeva G. M. et al. External endometriosis. Efficacy of laparoscopic surgery. Journal of obstetrics and gynecological diseases. 2002;LI(3):32-34. 9. Mahavolkna et al. Prevention of recurrence of external genital endometriosis Problems of reproduction. 2008;1:78-80. 
10. Makolkin V. I. et al. A variety of clinical symptoms of connective tissue dysplasia. Ter. the archive. 2004;76(11):77-80.

11. Shorohova M. A., Burlev V. A. Pathogenetic substantiation and modern principles of treatment for patients with endometriosis. Herald of the Russian obstetriciangynecologist. 2008;8(4):23-30.

12. Berry A. Century, Smooth N. N. Evaluation of a range of external phenotypic traits to identify small anomalies of the heart. Klin. honey. 2004;82(7):30-33.

13. Missmer S. A., Cramer D. W. The epidemiology of endometriosis. Obstet. Gynecol. Clin. North.Am. 2003;30(1):1-19.

\section{EFFECTIVENESS OF COMPLEX THERAPY FOR ENDOMETRIOID OVARIAN CYSTS DEPENDING ON THE PRESENCE OR ABSENCE OF UNDIFFERENTIATED DYSPLASIA OF CONNECTIVE TISSUE}

ALEKSANOVA E. M., AKSENENKO V. A.

It is established, that by carrying out the same therapy the frequency of pain syndrome returning after treatment is 1.5 times higher in patients with undifferentiated dysplasia of connective tissue than women without evidence of undifferentiated dysplasia of connective tissue. Increase in the level of CA-125 in blood serum, a year after the end of treatment was observed to be 2 times more frequent in patients with undifferentiated dysplasia of connective tissue than the patients in the comparison group. At the same time, studying the frequency of pregnancy in women with endometrioid ovarian cysts, it was found that when the number of phenotypic traits of undifferentiated dysplasia of connective tissue were less than 6 the pregnancy rate was 1.4 times higher than in the patients with the phenotypic traits of undifferentiated dysplasia of connective tissue more than 6 . In the group of patients with undifferentiated dysplasia of connective tissue frequency of adhesion processes in the pelvic was- 1.5 times higher and endometriosis recurrence rate was 2 times higher than in patients without undifferentiated dysplasia of connective tissue.

Key words: endometrioid ovarian cysts, dysplasia of connective tissue, endometriosis
14. Pyeritz R. E. Small molecule for a large disease. N. Engl. J. Med. 2008;358(26):2829-2831.

15. Schroder A. K., Diedrich K., Ludwig M. Medical management of endometriosis: a systematic review. I. Drugs. 2004;7(5):451-463.

16. Vigano P., Parazzini F., Somigliana E. Endometriosis: epidemiology and etiological factors. Best. Pract. Res. Clin. Obstet. Gynecol. 2004;18(2):177-200.

17. Weijenborg P. T., Kuile M. M., Jansen F. W. Intraobserver and interobserver reliability of videotaped laparoscopy evaluations for endometriosis and adhesions. Fertil. Steril. 2007;87(2):373-380.

\section{ЭФФЕКТИВНОСТЬ КОМПАЕКСНОЙ ТЕРАПИИ ЭНАОМЕТРИОИАНЫХ КИСТ ЯИЧНИКОВ В ЗАВИСИМОСТИ ОТ НААИЧИЯ НЕАИФФЕРЕНЩИРОВАННОЙ АИСПААЗИИ СОЕАИНИТЕАЬНОЙ ТКАНИ}

E. M. A^EKCAHOBA, B. A. AKCEHEHKO

Проведена оценка эффективности комплексной терапии эндометриоидных кист яичников в зависимости от наличия недифференцированной дисплазии соединительной ткани. Установлено, что при проведении одинаковой терапии частота возврата болевого синдрома после завершения лечения в 1,5 раза выше у пациенток с эндометриозными кистами яичников (ЭКЯ) при наличии недифференцированной дисплазии соединительной ткани (НДСТ), чем у женщин без признаков НДСТ. Повышение уровня СА-125 в сыворотке крови спустя год после завершения лечения наблюдалось в 2 раза чаще у пациенток с НДСТ, чем у больных группы сравнения. В то же время при изучении частоты наступления беременности у пациенток с ЭКЯ было установлено, что при числе фенотипических признаков НДСТ менее 6 частота наступления беременности была в 1,4 раза выше, чем у пациенток, число фенотипических признаков НДСТ у которых превышало 6. В группе больных с НДСТ частота спаечного процесса малого таза в 1,5 раза выше, а частота рецидивов эндометриоза - в 2 раза выше, чем у пациенток без НДСТ.

Ключевые слова: эндометриоидные кисты яичников, дисплазия соединительной ткани, эндометриоз 